\title{
[ When Men Give Birth: Production and Reproduction in John Steinbeck's Selected Works ]
}

\section{Karla Rohová}

University of Ostrava

[Abstract] The main goal of this paper is to reach beneath the surface of John Steinbeck's literary works in order to analyse the metaphorical connections between the long-term violence, abuse or oppression of women and the depletion of the land portrayed in several of his novels. For this purpose, excerpts dealing with the topic of production and reproduction in the works In Dubious Battle, To a God Unknown, "The Forgotten Village", East of Eden and The Grapes of Wrath are analysed to explore Steinbeck's depiction of the connection between the land and the female body.

[Keywords] production; reproduction; ecofeminism; John Steinbeck; nature; land; ecology; women; metaphor; California; agriculture

This text is an output of the project SGS04/FF/2019 "Ecocritical

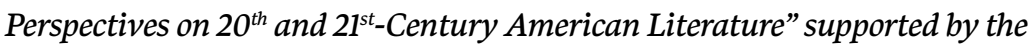
internal grant scheme of the University of Ostrava. 


\section{[1] Introduction}

The connection to the land can be seen in almost every book by John Steinbeck. In the past two decades, the author has been resurrected especially by environmental critics. Nevertheless, there is one figure which frequently recurs in his work and is specifically characteristic of the author's perception of nature - a woman.

Undeniably, to read John Steinbeck from an ecofeminist perspective is a journey full of controversial topics and evaluations which diverge in their meaning - a journey which most probably does not bring clear conclusions to the one who walks it. However, it definitely does offer a distinct approach to Steinbeck's style of writing and the way he views both the land and women - an approach which undoubtedly has the potential to add to the ongoing discussions about the woman/nature relationship and its validity.

Therefore, the main goal of this article is to explore Steinbeck's literary works focusing on the metaphorical connections between the long-term violence towards, abuse or oppression of women and the depletion of the land portrayed in several of the writer's novels. The article deals with the topic of the production of the land and the biological reproduction of individuals, more precisely with Steinbeck's manner of linking the female body with the body of the land, his means of erasing female generative power and shifting it into the hands of men, or elevating the generative powers of women with the generative power of the land. For this purpose, five of Steinbeck's literary works are critically analysed: In Dubious Battle (1936), To a God Unknown (1933), East of Eden (1952), “The Forgotten Village" (1941) and, finally, The Grapes of Wrath (1939).

\section{[2] Woman Metaphor as an Ecofeminist Issue}

While language is, without a doubt, not only an important part of literature but also (and primarily) an inseparable part of our society, sexist-naturist language could be viewed as an ecofeminist issue. For instance, Janis Birkeland argues that ecofeminism "offers a political analysis that explores the links between androcentrism and environmental destruction" and "begins with the realization that the exploitation of nature is intimately linked to Western Man's attitude toward women and tribal cultures" (18). She also adds that such values as the above-mentioned androcentrism or environmental destruction are deeply rooted within the minds of people living in the male-dominated West. Above all, Birkerland also blames patriarchal cultures for the woman-nature connection and for how both women and nature are controlled and exploited because of the establishment of this connection (18-20).

In fact, women are often "animalised" or "naturalised" in written or spoken words, which makes both them and nature - or animals - furtherly inferior to men, and thus condemns them to function as only servants in the male-dominated world. Warren explains that the language used to describe women and nature could be classified as sexist, stating that "the exploitation of nature and animals is justified by feminizing them; the exploitation of women is justified by naturalizing them" (Warren 12). 
In relation to Warren as well as in relation to Steinbeck, another concept which should be mentioned here is the feminisation of nature. Undeniably, the most discussed concept in ecofeminist circles is the concept of "Mother Nature" or "Mother Earth", two archetypes used in both literature and everyday speech. This personification and feminisation of the planet (or nature) has become even stronger in the past years given the rising fear of climate change and other factors which could cause the eventual death of our "Gaia". Chaia Heller comments on this phenomenon as follows: "In our modern iconography, nature became rendered as a victimized woman, a madonna-like angel to be idealized, protected, and saved from society's inability to constrain itself" (219).

When it comes to Steinbeck himself, critics such as Peter Lisca or Mimi Reisel Gladstein often depict his writing as misogynist (Lisca 207, Gladstein XX). Such a statement is important in order to understand that Steinbeck did not necessarily use the woman metaphor in order to help the oppressed group, or to help the "Mother Earth". Although his understanding of all men's burden touched women too, critics have still profoundly disapproved of his misogynist portrayal of women - a portrayal which does not give women the same freedoms and the same humanity that are granted to Steinbeck's men (Liang 1-6).

The main problem with Steinbeck's women, as the above-mentioned scholarly critics often argue, is the narrowness of the writer's female characters and therefore also the lack of different social roles assigned to them. Similar to other male authors of the first half of the $20^{\text {th }}$ century, Steinbeck tended to write his female characters more as objects which only complement the environment rather than actively shaping, changing or contributing to it. This especially applies to Steinbeck's three main types of female characters - the "whore", the "wife" and the "mother". Probably the best conclusion on the critical viewpoint of the degradative way in which Steinbeck wrote females in his fiction is offered through the following words by Peter Lisca: "In the world of his fiction women do have a place, but they seem compelled to choose between home-making and whoredom" (207).

On the other hand, there are voices that have explored Steinbeck's women, both in his novels and his personal life, such as the above-mentioned Peter Lisca or Sandra Beatty, and whose arguments or further analysis have given roots to different perspectives. One that is presented by Beatty even connects Steinbeck's female characters with nature: "[B]ecause of their closeness to Nature and to the Creator Himself, [they] instinctively understand both human nature and life, which make the need to comprehend their implications and complexities unnecessary" (qtd. in Bryer 591). In addition, Nikki Marie Garcia, for example, wrote in support of Steinbeck's "minor characters". Women, according to her, play a role whose importance transcends the number of pages devoted to female characters throughout Steinbeck's novels. Moreover, Garcia argues that the characters of Ma Joad in The Grapes of Wrath and Cathy in East of Eden might be used as a proof of Steinbeck's attempt to break out from the traditional characterisation of the roles assigned to women at the time when he was writing (Garcia 23-34).

Undeniably, Steinbeck seems enchanted with the female body and everything that it is capable of. Above all, his tendency is to repeat a specific narrative which deals with 
the production of the land as well as with female and oftentimes even animal reproduction. Childbirth is an important element in several of Steinbeck's novels, particularly in In Dubious Battle, To a God Unknown, "The Forgotten Village", East of Eden and The Grapes of Wrath. However, for Steinbeck's characters, childbirth is not only an ability which the female body possesses; it is an activity closely related to the production of the land, and most importantly, it is an activity which Steinbeck's male characters take away from the female body in order to allow the men to appropriate the whole process of creation. Julianna Restivo comments that Steinbeck's scenes of childbirth are supposed to evoke "favour of the masculine over the feminine" (117).

On the other hand, considering the fact that men are not present in the physiological processes of pregnancy or giving birth, one might begin to understand their need to produce, create and, most of all, appropriate. According to Akiko Suzue, Steinbeck even "thought of childbirth being too important to leave in the hands of women" (73). In reality, Steinbeck mostly deals with the issue of childbirth by moving the female "to the side" and by appropriating the process of production as well as the process of birth. In different words, Steinbeck is ultimately allowing his male characters to "give birth", either through their land or through the female body - and if they are robbed of the ability to produce and reproduce, the men gradually become weaker and the female-led childbirth or female leadership generally ends in disaster, as happens in The Grapes of Wrath. Restivo explains the behaviour of Steinbeck's male characters by stating that the majority of them clearly feel the need to "re-appropriate the powers lost to men" by annexing and taking full domination over the land (Restivo 118). To conclude this introduction into "male birth", it would be appropriate to relate this theme more closely to the production that is associated with the land.

\section{[3] In Dubious Battle}

First published in 1936, In Dubious Battle is a novel whose central plot is dominated by the organisation of men for revolution. The phalanx narrative ${ }^{2}$ which Steinbeck uses in the book recounts events which have the purpose of giving men full control over the production of the land. Even so, Steinbeck does not resist dedicating certain parts of the novel to the female body and female generative power, as if he saw no other way than to include the process of childbirth as a part of the dreamed-of revolution. However, as John Seelye points out, In Dubious Battle is “intensely male-centred, with only marginal roles for women" (27) and the generative power of the female body serves mainly to secure men's power - in particular, the whole organisation of men's power - over the land (Restivo 119120). This will be made clear by analysing the scene in which Lisa gives birth to her child.

Before the actual birth takes place, Steinbeck lets Mac enter the scene of childbirth. Although the man only pretends to have the knowledge of a doctor, he ultimately uses his interference in the delivery of Lisa's baby in order to proceed with organising the men. The male character is determined to use his interference as a way to be accepted by the whole group and to paint himself as a trustworthy person. During the childbirth, 
Lisa's husband London comments on the midwife, the old woman who is supposed to deliver the baby, by questioning her mental stability. This could be understood as London's immediate favouring of Mac's supposed "ability" to help deliver the baby over the old woman's knowledge or experience, even though Mac has not demonstrated his knowledge yet. However, this is not the end of Steinbeck's denigration of the woman's involvement in the delivery; he continues by depicting why Mac would be a better choice for the role of a "doctor":

Mac turned to the old woman. "You a midwife?" She scratched the backs of her wrinkled hands and looked vacantly up at him, but she didn't answer. "I asked if you was a midwife?" he cried. "No - but I've took one or two babies in my life.” Mac reached down and picked up one of her hands and held the lighted candle close to it. The nails were long and broken and dirty, and the hands were bluish-grey. "You've took some dead ones then," he said. (Steinbeck, In Dubious Battle 67-68)

In the excerpt above, Steinbeck describes the old woman's appearance as more than dubious, and through Mac's verdict, ultimately condemns the woman's ability to deliver the baby as non-existent. Restivo explains that while Steinbeck distinguishes female production as "dirty and backward", the male production in In Dubious Battle equals "scientific sterility" (119), no matter that Mac's level of knowledge when it comes to gynaecology is, without doubt, low. What is more, Steinbeck accomplishes what seems to be his goal even in various other novels - he pushes the pregnant female body to the margin, and brings the fate of the land to the centre. In In Dubious Battle, as has been mentioned above, the centre of the story is the phalanx narrative, of which the reader is reminded even when Lisa gives birth to her baby. Although Mac functions as the leader - the "director" of the whole process - he demands help from the rest of the men and therefore organises the men as a collective unit:

A change was in the air. The apathy was gone from the men. Sleepers were awakened and told, and added themselves to the group. A current of excitement filled the jungle, but a kind of joyful excitement. Fires were built up. Four big cans of water were put on to boil; and then cloth began to appear. Every man seemed to have something to add to the pile. One took off his undershirt and threw it into the water and then put on his shirt again. The men seemed suddenly happy. They laughed together as they broke dead cottonwood branches for the fire. (Steinbeck, In Dubious Battle 69-70)

What might have been the delivery of a baby as a process controlled by three people - one old woman (a midwife), Lisa, and possibly also her husband, i.e. the number of people typically present during the natural process of childbirth - suddenly becomes an event of relevance to the organisation of men, an event which is essential for the men and their struggle for the land. As Restivo hints, Lisa's body becomes "a medium for male formation and production", all for the future sake of the land (119). This alone could be considered an idealistic notion presented by Steinbeck - a childbirth connecting indi- 
viduals, and above all revolutionaries, together. However, this is also a revolution at the expense of a woman whose body and childbirth are appropriated without her consent.

Considering Mac's main intervention, he poses as the leader and thus not only appropriates "the central figure of production" but also, through the child's birth, evolves into "a male mother" (Restivo 120). Moreover, it is essential to once again note Lisa's enforced passivity. While Mac gives instructions to the group of men and is able to register even the small boy fainting in the corner of the tent, Lisa is only able to experience contractions, though none of them are directly described, and she delivers the baby in silence, with practically no scream of her own: "The baby's head appeared. Mac supported it with his hands, and while Lisa squealed weakly, the birth was completed. Mac cut the cord with a sterilized pocket-knife" (71).

Again, Mac's male sterility is put to the forefront, and the reader cannot help noticing his faked expertise. When the old woman comes forward to at least collect and take care of the newborn baby while Lisa is recovering, Mac allows her to do so only after Jim properly washes her hands. What is more, all evidence of the birth, even donated cloths which were never used, gets burned on Mac's command, which the character later explains as follows: "Every man who gave part of his clothes felt that the work was his own. They all feel responsible for that baby. It's theirs, because something from them went to it. To give back the cloth would cut them out" (72-73).

To conclude, in a single scene, Steinbeck successfully enables the character of Mac to take over the delivery of the baby, and in the end to appropriate the female body as well as the whole process of production. In this story, Lisa represents the only female generative power, only to have that power taken away as a means of Mac's assimilation into the group of men. The moment is crucial in the story, as it introduces the phalanx narrative. Later in the novel, Mac adapts the same method in order to achieve the group's main goal - to appropriate the land. Consciously or not, Steinbeck constructs a link between the female body and the body of the land, and "gives birth" to male production, which becomes the central tool in the appropriation of the land as well as in the rebellion against the system (Restivo 118-120, Seelye 27-29).

\section{[4] To a God Unknown}

Steinbeck's third novel explores reproduction through Elizabeth's labour as well as Joseph Wayne's relationship towards the land, once again linked with the female body. Hisako Osuga argues that Joseph, the main character, is "the fountainhead of fertility" (50). In the excerpt below, Joseph shows his powerful devotion to the land and the living beings dependent on it by making himself "the root of their fertility": "All things about him, the soil, the cattle and the people were fertile, and Joseph was the source, the root of their fertility; his was the motivating lust. He willed that all things about him must grow, grow quickly, conceive and multiply" (Steinbeck, To a God Unknown 26-27).

Joseph puts himself in the position of the one who controls the fertility (and consequently also the production) of not only the land but also "the cattle and the people" 
(Steinbeck, To a God Unknown 26-27). In Joseph's case, the process of appropriation covers not only female reproduction, but also animal reproduction. In the end, the main character marvels at every birth on his farm and controls the breeding of his animals with precision. As Restivo points out, the generative power in To a God Unknown is "heavily male-oriented" (120). This is especially prominent in the depiction of Joseph's involvement in Elizabeth's pregnancy. While Joseph worries about Elizabeth's well-being and tries to lecture her on the matter, she replies with confidence that "a whole plane of knowledge opens when a woman is carrying a child" (102-103). Although Joseph is not satisfied with Elizabeth's words and continues to control her pregnancy, his reasons for worrying are not related to his wife or to their child, but to the connection of Elizabeth's pregnancy with the earth, as demonstrated in his own explanation: "Yes - the child is precious, but not so precious as the bearing of it. That is as real as a mountain. That is a tie to the earth.' He stopped, thinking of words for the feeling. 'it is a proof that we belong here, dear, my dear. The only proof that we are not strangers'" (102-103).

Through the explanation of his worries, Joseph constructs a direct connection between Elizabeth's body and the earth. Furtherly, Joseph's claim of this connection is "the proof of his ties to the land" (Restivo 120). Nevertheless, Joseph carries on connecting Elizabeth's pregnancy to the earth, saying that pregnant women "take up the nerve-ends of the earth in their hands" (Steinbeck, To a God Unknown 113). In this case, Steinbeck could be also referring to the image of the human placenta, which, if delivered through labour, resembles the roots of trees - as do the nerve endings in human body.

Later in the novel, during Elizabeth's labour, Joseph takes control over female generative power and eventually appropriates it. Although he does not have knowledge or experience of assisting with childbirth, he forces himself between Elizabeth and Rama, arguing that "it's a thing for me to do" (117). As in In Dubious Battle, Joseph controls the childbirth and moves Elizabeth's body to the periphery, making it only "a passive site of male domination" (Restivo 121). Similar to Mac, he becomes the central figure of the delivery. Moreover, after the labour ends, Joseph steps outside and becomes aware of the consequences of his physical involvement in the labour, as if he was the one who had experienced the pain instead of Elizabeth. Steinbeck even writes that "his stomach still racked with the pains he had received from Elizabeth" (118-119).

"It's a boy," he said it up against his chest with a bandage." "Was it a hard birth?" Thomas asked. "I came out here to keep from going in to help." "Yes, it was hard, and Rama said it was easy. God, how the little things fight against life!" (Steinbeck, To a God Unknown 119)

Finally, by appropriating Elizabeth's body, Joseph crowns himself as "the mother to both the land and the baby" (Restivo 121). Before the above-cited conversation occurs, Joseph constructs one more connection between the process of childbirth and the earth, specifically to his tree, uttering "you are the cycle" while he passes it on his way (Steinbeck, To a God Unknown 119). No matter if it was during Elizabeth's pregnancy, during her labour or after it, Joseph seems to complete the cycle that he has created for himself by conjoining 
Elizabeth's body or her pregnancy, the land and himself, objects which are all fully within his control - objects which, he assumes, would not exist without him.

\section{[5] East of Eden}

Mark Seltzer, the author of Bodies and Machines (1992), argues that at the end of the $19^{\text {th }}$ century the stream of naturalism evident in novels of the time tried to "replace female generative power with an alternative practice, at once technological and male" (28). Nowadays, there are many other novels or short stories which contain similar scenes, such as Ernest Hemingway's "Indian's Camp" (1924). Of course, Steinbeck belongs to this category, as has already been pointed out in the previous two analyses; however, in East of Eden, the impact of male-dominated technology on the generative power of the female character Cathy is much more prominent.

Before demonstrating this, it would be appropriate to insert a brief introduction to the powerful character Cathy Trask. To one group of critics, Cathy is Steinbeck's strongest and most prominent female character, but she does not play the role of a hero, unlike her male counterparts. She is an antagonist; often used by critics as a proof of Steinbeck's misogynist views of women. Nikki Garcia, however, argues that Cathy is the one female character who breaks free from the typical writing scheme which Steinbeck used for most of his female characters (24-34). Cathy refuses to be passive, to be moved aside by her husband, the doctor or the land. The best demonstration of her refusal of passivity is during yet another scene of childbirth:

Her head jerked up and her sharp teeth fastened on his hand across the back and up into the palm near the little finger. He cried out in pain and tried to pull his hand away, but her jaw was set and her head twisted and turned, mangling his hand the way a terrier worries a sack. A shrill snarling came from her set teeth. (Steinbeck, East of Eden 145)

The key point of the scene which concerns this analysis is the bite that Samuel receives from Cathy. As a male with knowledge of medicine, Samuel represents modern technology, and he is also the one who attends Cathy's labour as a doctor, thus appropriating the female body as well as the power of production. However, Cathy tries to stop the male control over her body even sooner in the story by her attempt to abort her children. This move - expressing her independent choice in regards to her own body - is criticised by a man, her doctor, and Cathy is forced into motherhood, regardless of the fact that she is mentally (and later also physically) unable to do so. In the story, Cathy refuses to nurture her children and therefore rejects what is natural for her body - she rejects her ancient connection to nature. This is an important aspect to highlight, as the whole story, dominated by a strong female character and her refusal to be controlled or have her generative power appropriated, involves a land which does not flourish in production. Unfortunately for Cathy, she does not undergo the difficulties related to pregnancy because of her free will, but she becomes a tool, a machine for the men around her who want to hold control 
over the land as well as over female reproduction. Restivo explains that Steinbeck's characters once again favour the "male-mother model" and men's control of the means of production (123).

In the end, Cathy's impassiveness does not bring the man, her husband, any benefit; she is presented as the female power of destruction. Steinbeck describes the Wise Woman of the following text "The Forgotten Village" in a similar way; however, in the case of East of Eden, Cathy does not hold power over the land, yet her choice to leave her children and her husband causes the future of Adam's land to remain unchanged, and the soil continues to be in its untouched form, unploughed and unfarmed.

As has been mentioned above, East of Eden is also a novel which explores the clash between technology (attributed to men) and non-industrial agriculture, or in different words, "the old way of living" (mostly attributed to women). Samuel Hamilton, "the male mother" of this story as Restivo calls him, demonstrates this even before the birth takes place. The first indication of this clash is when Samuel speaks of his ability to attend the birth of different farm animals, in which category he includes even women (Restivo 122-124). The important moment, however, comes when Cathy's labour starts and Samuel is called in to help. After that, he says "first we find a buried star and now we go to dig up a mint-new human"; this may indicate his male control over modern technologies such as mining, or as Samuel calls it “digging up" (Steinbeck, East of Eden 145). Through Samuel's commentary about the day's events, Steinbeck once again connects female generative power to the land.

\section{[6] The Forgotten Village}

"The Forgotten Village" offers an insight into the ancient life of the Mexican people. This short story, which Steinbeck wrote for a movie of the same name released in 1941, aimed at examining the differences between new technology and old beliefs, between Western medicine and ancient magic, between modern and pagan ways of living. Though considered to be one of the shortest works written by Steinbeck, it includes an important discussion about the clash between old and new, a theme that is present in more than one of his novels - and also a theme that is almost omnipresent in both old and modern society. Steinbeck refers to this subject in the preface of the story as follows: "What we found was dramatic - the clash of a medicine and magic that was old when the Aztecs invaded the plateau with a modern medicine that is as young as a living man" (Steinbeck, “The Forgotten Village" 9-10).

Nonetheless, like the previously analysed novels, "The Forgotten Village" contains a scene of childbirth. The difference comes in the presence and meaning of the central character, the Wise Woman called Trini, who is "the doctor", the magician and the Mother of the whole village. In contrast to In Dubious Battle or To a God Unknown, Trini holds the power which the men in the aforementioned novels want - and, in the end, successfully appropriate. While making the movie, Steinbeck writes in the preface of the short story, “our curandera ${ }^{3}$ was a real 'wise woman,' one who practiced herbology and magic 
in the village; our teacher was a real teacher in the government school; our doctors real doctors; our mother a real mother who had lost a number of children" (Steinbeck, "The Forgotten Village" 9-10); this already creates an image of realness and moreover draws attention to the contrast between the curandera of the village and the newly arrived foreign doctors.

Having said that, while Trini represents the old and pagan way of living, Juan Diego, a young boy who turns against the traditional life in the village, represents modern technology. Similarly as in In Dubious Battle, the female, curing the villagers through herbs, eggs, snake skin or other natural remedies (things which, as Restivo points out, represent "Mother Earth"), is almost automatically associated with devastation (124). Trini's destructive power is best demonstrated when she destroys the real medicine which the men bring, which is intended to save the boy Paco: "'You will kill the people with your new foolishness. This for your nonsense!' And she threw his medicines to the ground" (Steinbeck, “The Forgotten Village” 35-36).

The Wise Woman disapproves of the world of modern technology represented in the men. She openly, though falsely, debunks the men's medicines as a tool for killing - they do not come from nature or the land, things controlled by the female, the Mother Earth. In the end, she is the force that drives the villagers to annihilation. Therefore, Steinbeck creates the image of the female who is supposed to represent a force that destroys modern technology (Restivo 124-125).

If the death of the pregnant mother's child was not demonstrative enough, Steinbeck gives the reader yet another scene of childbirth, this time "directed" by the female Mother of the village - it is like a mirror of the scenes of female-led production in the previous novels, specifically reflecting the men's role in the whole process.

The Wise Woman worked her magic, and chanted the old words: "Now he is forming, Now he is ready. Now he has hands. Now he has eyes. Now he is forming." When the birth was near, they awakened the father to give strength and comfort to the mother. Between his knees he held her and braced her against her pain, and took some of the pain to himself. And Trini worked with the last labor. She chanted, "Now he is formed, now he is ready." The father whispered in Esperanza's ear, "Be of good courage, I am with you. Be of good courage, I am with you." And Trini cried in triumph, "He is formed - he is born! He is here!" (42-44)

This time, the man is moved to the periphery. In fact, the father of the baby and the rest of the family are in tune with the Wise Woman's scheme. Although the mother is again passive, apart from the mention of pain there is no word about her physical or mental experience of the labour; the important thing which happens during the production is Trini's chanting at the infant. Representing magic and most of all nature, the Wise Woman is the Mother Earth's voice forming the infant's body little by little; the voice gifting the infant with his life. In other words, she is the Mother Earth standing above the creation happening in front of her eyes and led by her hands - i.e. the position which the men in previous novels appropriated and took away from the control of females. 
However, the story's goal is not to praise the pagan way of living; with the children and the baby dying, Steinbeck's aim to discredit beliefs in old magic and nature - and with that also beliefs in female generative powers - comes to a successful fulfilment. Although disturbing, the story ends, similarly as in the following text The Grapes of Wrath, with a hopeful scene. Juan Diego occupies a laboratory, possibly involved in modern technology. One might hope that in consequence he will able to change the future of the village by taking control over it - and with that, as Restivo points out, also over the land and the production power (125):

"And the change will come, is coming; the long climb out of darkness. Already the people are learning, changing their lives, learning, working, living in new ways. "The change will come, is coming, as surely as there are thousands of Juan Diegos in the villages of Mexico.” And the boy said, "I am Juan Diego.” (Steinbeck, “The Forgotten Village" 78-80)

\section{[7] The Grapes of Wrath}

The "Okies" in The Grapes of Wrath, specifically the Joads family, move through their industrialised and machine-filled transformation against the laws and rhythms of nature, even though Steinbeck takes many opportunities to remind both the family and the reader of the existence of the cycle of nature (Railton 102-103). This novel, often considered to be Steinbeck's masterpiece, is a social manifesto highlighting and commenting on various issues - such as immigration and its consequences or causes, which are favourite topics of discussion in different parts of the world even nowadays. In the case of The Grapes of Wrath, Steinbeck also chooses to demonstrate his view on these issues through the journey of the Joads family; however, what seems to be even more important than the members of the migrating family is, of course, their land.

As has been mentioned in the introduction to this analysis, The Grapes of Wrath explores the connection of men to the land through the body of a female, in this case the pregnant body of one of the female characters, Rose of Sharon. Restivo claims that "the female body is instrumental of Steinbeck's critique" (125). In fact, The Grapes of Wrath portrays the disaster which unfolds if men lose control over their land, or if the land is controlled by people who do not sustain life on the land, but rather destroy it.

Nevertheless, with the destruction of the land comes not only the destruction of the men's power to control. The Grapes of Wrath depicts the same connection of the female body and the land, but as opposed to In Dubious Battle or To a God Unknown, the connection is apparent in the destructive results - both the female body and the land are infertile, and they both suffer from the absence of male control over their production (Restivo 125-128).

This is obviously best displayed during the scene of Rose of Sharon's childbirth. Even before the labour fully unfolds, Rose of Sharon's body is already connected to agriculture and the land: 
Down by the mattress, in the bright light of the lamp, Ma and Mrs. Wainwright held conference. Their voices were raised a little over the hollow beating of the rain. Mrs. Wainwright took a paring knife from her apron pocket and slipped it under the mattress. "Maybe it don't do no good," she said apologetically. "Our folks always done it. Don't do no harm, anyways." Ma nodded. "We used a plow point. I guess anything sharp'll work, long as it can cut birth pains. I hope it ain't gonna be a long one." (Steinbeck, The Grapes of Wrath 302)

This "plow point" and its replacement by a "paring knife" symbolise the absence of non-industrial agriculture and the loss of their own land. Due to this loss, Rose of Sharon is cut off from "the life-giving properties of the land and agriculture", resulting in the unfortunate death of her child (Restivo 126).

As men in The Grapes of Wrath lose the control over production, they are also placed at the periphery during Rose of Sharon's labour. Moreover, according to Restivo, production seems to be controlled by the forces of nature rather than by the men (126-127). Rose of Sharon's pregnant body seems to mirror the behaviour of the environment, especially in the last part of the novel. While flood waters hit the valley of the Joads' temporary home, Rose of Sharon's body prepares for the upcoming labour. Both flooding and Rose of Sharon's labour are, in the end, completely outside the control of men.

What is more, while women help Rose of Sharon through the delivery of her unfortunately stillborn child, the men instead take a chance to grasp control over at least one of the events, this time tied to the seemingly "uncontrollable" nature, by building a barrier to stop the upcoming flooding. The male characters are then implicitly contrasted with the women assisting the delivery of Rose of Sharon's child. Steinbeck describes that "they worked jerkily, like machines" (303), creating a "technological" or possibly "artificial" opposition to nature and its forces. Earlier in the story, Rose of Sharon's mother draws a similar comparison; however, in this case, she also explicitly includes women in it. While men are compared to machines - "lives in jerks" (291) - women are, on the other hand, compared to the river, which signals that men are "excluded from the means of production" and "face nature differently than women" (Restivo 126).

"An' that's one more thing a woman knows. I noticed that. Man, he lives in jerks baby born an' a man dies, an' that's a jerk - gets a farm an' loses his farm, an' that's a jerk. Woman, it's all one flow, like a stream, little eddies, little waterfalls, but the river, it goes right on. Woman looks at it like that. We ain't gonna die out. People is goin' on - changin' a little, maybe, but goin' right on." (Steinbeck, The Grapes of Wrath 291)

Richard E. Hart argues that Steinbeck's views about nature were at times contradictory. Hart comments that Steinbeck understood nature "as both friend and enemy" (49). In the novel, the two events - the men's struggle against nature's forces and the childbirth seem to unfold at the same time, and both - although natural and unstoppable - represent a danger to the characters. Therefore, the falling of the tree and the flood waters 
entering the earth's “canal" epitomise Rose of Sharon's labour, which, similarly to the tree or the building of the barrier, proceed to end in disaster. The fallen tree, specifically, might be viewed as the embodiment of Rose of Sharon's body deprived of the ability to bring a healthy child to life (Restivo 125-127, Hart 49-50):

Then, from up the stream there came a ripping crash. The beam of the flashlight showed a great cottonwood toppling. The men stopped to watch. The branches of the tree sank into the water and edged around with the current while the stream dug out the little roots. Slowly the tree was freed, and slowly it edged down the stream. The weary men watched, their mouths hanging open. The tree moved slowly down. Then a branch caught on a stump, snagged and held. And very slowly the roots swung around and hooked themselves on the new embankment. The water piled up behind. The tree moved and tore the bank. A little stream slipped through. (Steinbeck, The Grapes of Wrath 304)

Finally, the work of the men is destroyed by the "enemy" which nature has become, and Rose of Sharon's child is killed by the "enemy" that has appropriated the land of the family.

\section{[8] Conclusion}

The main aim of this article has been to analyse the woman/nature relationship (with the emphasis on ecofeminist aspects) in selected works by the American writer John Steinbeck. For this purpose, an introduction to Steinbeck's use of the woman metaphor is given, and the established notion of Steinbeck's misogyny (regarding his female characters) is presented. Critical approaches which seem to either support or oppose this viewpoint are pointed out.

The analysis then specifically focuses on Steinbeck's use of the theme of production and reproduction in his writings about nature and the Californian land. From the very beginning of the analysis, it is made apparent that for Steinbeck's characters - and male characters in particular - childbirth is not a process dominated by women and their bodies. In fact, the majority of childbirths (or even entire pregnancies) are fully dominated by male characters. What is more, childbirth as well as pregnancy are both strongly related to the production of the land - and most importantly, it is an activity which Steinbeck's male characters take away from the female body in order to allow the men to appropriate the whole process of creation in the story.

Nevertheless, the excerpts dealing with production and reproduction show not only the depiction of the connection between the land and the female body, but also the writer's attempts to allow his male characters to "give birth" - or, as the analysis shows, to appropriate female generative power and become the "Male Mothers" of both the land and the newborn children.

Clearly, through his novels and the topics that he dealt with, Steinbeck managed to give voice to many voiceless communities across the world, including the "Mother Earth". However, as has been shown in this article, in the novels discussed here he fails 
to give voice to women, although he repeatedly borrows their bodies in the form of an absent referent of sexist-naturist descriptions of the land or female characters.

\section{[Notes]}

${ }^{1}$ A narrative which includes and centres around the organisation of men for the purpose of a battle or, in the case of Steinbeck's In Dubious Battle, for the purpose of a revolution. ${ }^{2} \mathrm{~A}$ term which originated in Latin America and represents a traditional healer who uses natural and folk remedies, including magic.

\section{[Bibliography]}

Birkerland, Janis. "Ecofeminism: Linking Theory and Practice." Ecofeminism: Women, Animals, Nature. Ed. Greta Claire Gaard. Philadelphia: Temple University Press, 1993. 13-59. Print.

Bryer, Jackson Robert. Sixteen Modern American Authors: A Survey of Research and Criticism. Durham: Duke University Press, 1990. Print.

Garcia, Nikki Marie. Steinbeck's Female Characters: Environment, Confinement, and Agency. Thesis. ALM, Harvard Extension School, May, 2016. Belknap: Harvard U, 2016. Harvard Library. Web. 03 Apr. 2019. http://nrs.harvard.edu/urn3:HUL.InstRepos:33797290.

Gladstein, Mimi Reisel. The Indestructible Woman in Faulkner, Hemingway, and Steinbeck (Studies in Modern Literature). UMI Books on Demand, 2004.

Hart, Richard E. "On Man and Nature." Steinbeck and the Environment: Interdisciplinary Approaches. Ed. Susan F. Beegel et al. Tuscaloosa: University of Alabama Press, 1997. 49-50. Print.

Heller, Chaia. "For the Love of Nature: Ecology and the Cult of the Romantic." Ecofeminism: Women, Animals, Nature. Ed. Greta Claire Gaard. Philadelphia: Temple University Press, 1993. Print.

Liang, Shu fang. "Critics' Views on the Female Characters in John Steinbeck's Works." Kaohsiung: Fooyin University, 1994. Fooyin University Institutional Repository. Web. 3 March 2019. https://ir.fy.edu.tw/ir/.

Lisca, Peter. The Wide World of John Steinbeck. New York: Gordian, 1981. Print.

Osuga, Hisako. "Women Wanting to Be Mothers, Women Refusing to Be Mothers: Motherhood as a Predominant Theme in Steinbeck's Fiction." John Steinbeck, Global Frameworks: Selected Papers from the Sixth International Steinbeck Congress Held in Kyoto, Japan on June 6-9, 2005. Eds. Yoshifumi Kato and Scott Pugh. Osaka, Japan: Osaka Kyoiku Tosho, 2007. 41-57. Print.

Railton, Stephen. "Okies' Transformation from Personal to Political Struggle." Industrialism in John Steinbeck's The Grapes of Wrath. Ed. Louise Hawker. Detroit: Greenhaven, 2008. 102-03. Print. 
Restivo, Julianna. “Steinbeck's Pregnant Bodies: Childbirth, Land, and Production.” The Steinbeck Review 12.2 (2015): 117-29. Print.

Seelye, John. "Steinbeck and Sentimentality.” Beyond Boundaries: Rereading John Steinbeck. Eds. Susan Shillinglaw and Kevin Hearle. Tuscaloosa: University of Alabama Press, 2002. 27-29. Print.

Seltzer, Mark. Bodies and Machines. New York: Routledge, 1992. Print.

Steinbeck, John. East of Eden. London: Penguin Books, 2007.

---. In Dubious Battle. London: Penguin Books, 2006.

---. The Grapes of Wrath. London: Penguin Books, 2006.

--- . To a God Unknown. London: Penguin Books, 2000.

Steinbeck, John, et al. The Forgotten Village: with 136 Photographs from the Film of the Same Name. London: Penguin Books, 2009.

Suzue, Akiko. “Sex, Reproduction and the Sacrifice of Life in Steinbeck's Fiction.” John Steinbeck, Global Frameworks: Selected Papers from the Sixth International Steinbeck Congress Held in Kyoto, Japan on June 6-9, 2005. Eds. Yoshifumi Kato and Scott Pugh. Osaka, Japan: Osaka Kyoiku Tosho, 2007. 24-36. Print.

Warren, Karen J. Ecofeminism: Women, Culture, Nature. Bloomington: Indiana University Press, 1997. Print.

\section{[Address]}

Department of English and American Studies

Faculty of Arts

University of Ostrava

Reální 5,

70103 Ostrava

Czech Republic

karlarohova@gmail.com

Karla Rohová is a MA student of English Philology at the University of Ostrava. In both her studies and her publications, she focuses on the examination of literary works from ecofeminist, gender and ethnic perspectives. Apart from English and American studies, she also devotes her time to creative writing, especially to poetry. 